\title{
STAGING IN THE HYPERGENE TRANSFORMATION OF SULPHATE AND CARBONATE ROCKS (BASED ON SLIDE-ROCKS UNDER ORGAN TUBES IN KUNGUR ICE CAVE)
}

\author{
VPOGLED V HIPERGENO PREOBRAZBO SULFATNIH \\ IN KARBONATNIH KAMNIN (TEMELJEČ NA POLZEČIH \\ ODLOMKIH KAMNINE POD »ORGELSKIMI CEVMI« \\ V KUNGURSKI LEDENI JAMI)
}

\author{
Olga KADEBSKAYA ${ }^{1} \&$ Ilya TCHAIKOVSKIY ${ }^{1}$
}

\begin{abstract}
UDC 551.44:551.584(470.53)

Olga Kadebskaya \& Ilya Tchaikovskiy: Staging in the hypergene transformation of sulphate and carbonate rocks (based on slide-rocks under organ tubes in Kungur Ice Cave)

The article describes the influence of microclimate on the constitution of talus cone deposits in the grottoes of Kungur Ice Cave. Deposits of slide-rocks collapsed from «organ tubes» in different climatic zones of the cave were investigated. It was established that slide-rock material has identical initial composition, but is transformed in different ways depending on the microclimate in which it is deposited. In the cold zone of the cave, with temperatures below $0{ }^{\circ} \mathrm{C}$ control («freeze») the transformation of carbonate and sulphate materials. The main processes of mineral formation in cold zone are connected with cryogenic mineralization from sulphate and carbonate waters. Slide-rocks in the transition zone of the cave, where temperatures range from $0{ }^{\circ} \mathrm{C}$ to $3{ }^{\circ} \mathrm{C}$, are distinguished by the presence of authigenic carbonate breccias and a variety of gypsum forms. In the warm zone of the cave, slide-rock undergoes complete dissolution of gypsum and partial dissolution of carbonate debris. In the future changes of paleoclimatic conditions in the karst cavity can be identified by investigation of deposits that are climatic markers.

Keywords: Karst massif, Microclimate, Rock transformation, Cryogenic mineralization, Kungur Ice Cave (Ural Mountains).
\end{abstract}

Izvleček

UDK 551.44:551.584(470.53)

Olga Kadebskaya \& Ilya Tchaikovskiy: Vpogled v hipergeno preobrazbo sulfatnih in karbonatnih kamnin (temelječ na polzečih odlomkih kamnine pod "orgelskimi cevmi« v Kungurski ledeni jami)

Članek opisuje vpliv mikroklime na oblikovanje talusnega stožca v rovih Kongurske ledene jame. Preiskovani so bili polzeči nakopičeni odlomki kamnine, ki so odpadli iz sten tako imenovanih "orgelskih cevi« $\mathrm{v}$ različnih klimatskih območjih jame. Ugotovljeno je bilo, da ima polzeči material enako začetno sestavo, vendar se preoblikuje na različne načine, odvisno od mikroklime v kateri se nalaga. $\mathrm{V}$ hladnih delih jame, temperature pod $0{ }^{\circ} \mathrm{C}$ kontrolirajo (zmrzovanje) preoblikovanje karbonatnih in sulfatnih materialov. Glavni procesi nastajanja mineralov v mrzlih območjih so povezani s kriogeno mineralizacijo iz sulfatnih in karbonatih vod. Polzeče odlomke kamnine v prehodnih delih jame, kjer temperature nihajo med $0{ }^{\circ} \mathrm{C}$ do $3{ }^{\circ} \mathrm{C}$, zaznamujejo prisotnost avtigenih karbonatnih breč in raznolike oblike sadre. $\mathrm{V}$ toplih delih jame, so polzeči odlomki kamnine podvrženi popolni raztopitvi sadrinih in delni raztopitvi karbonatnih klastov. V prihodnosti se bo lahko zaznavalo spremembe mikroklime $\mathrm{v}$ kraških jamah $\mathrm{z}$ raziskavami talusnih sedimentov, ki so odlični klimatski markerji.

Ključne besede: kraški masiv, mikroklima, preobrazba kamnin, kriogena mineralizacija, Kungurska ledena jama.

\section{INTRODUCTION}

Kungur Ice Cave is located in Eastern Europe on the outskirts of the old Russian town of Kungur. In the physical geography terms, the cave area is located in the Eastern part of the Russian (East European) Plain and is confined to the juncture of two geographical areas - High Trans-
Volga (Zavolzhye) and the Ufa plateau. The region is often called Pre-Urals due to its vicinity (about $100 \mathrm{~km}$ ) to the Ural mountain range.

The cave is widely known in Russia and abroad as the most interesting and most-visited speleological and

\footnotetext{
${ }^{1}$ Mining Institute of Ural Branch of Russian Academy of Sciences, Sibirskaya 78a, 614007 Perm, Russia; e-mail: icecave@bk.ru Received/Prejeto: 22.05.2015
} 

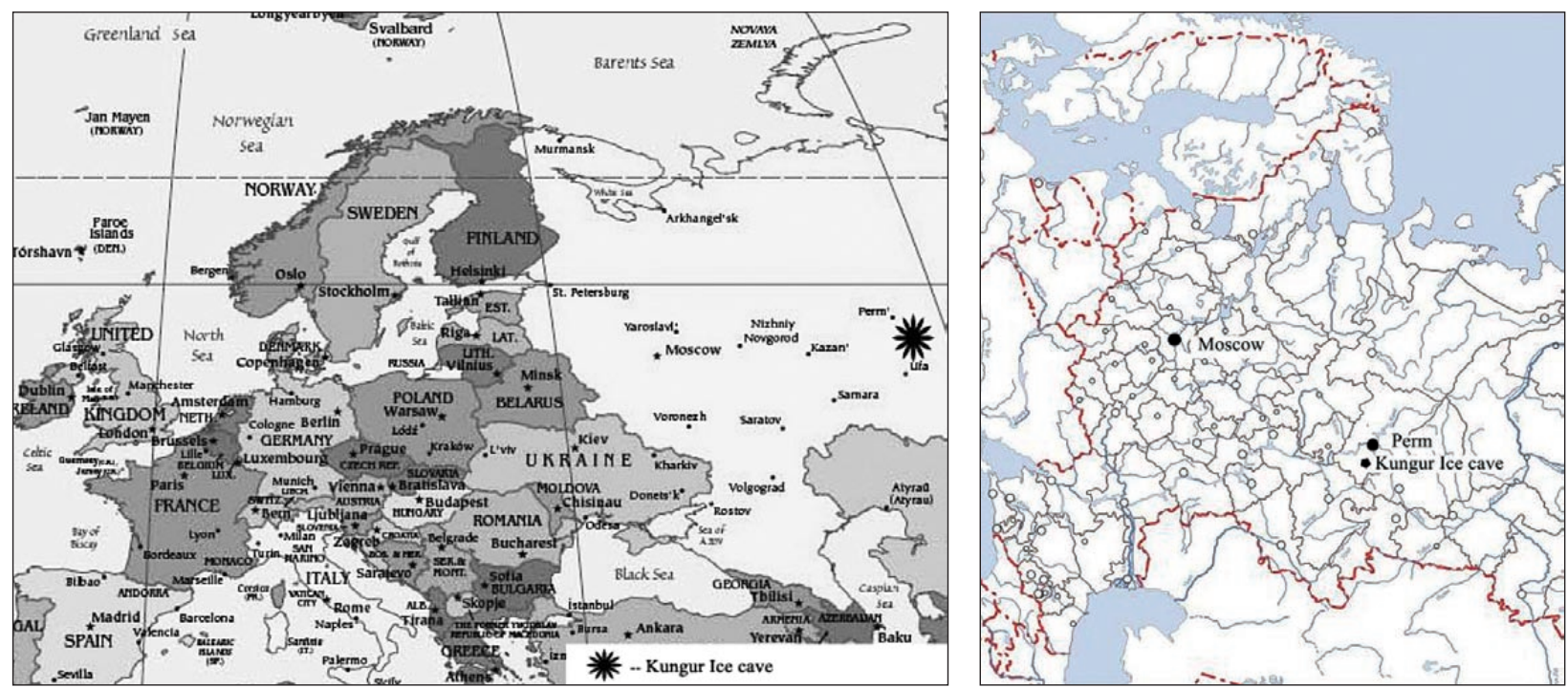

Fig. 1: Location of Kungur Ice Cave on the background of the Eastern Europe.

tourist object and it serves as a kind of «visiting card» of the Perm Krai region. Over 5 million tourists have visited the cave since the early $20^{\text {th }}$ century. In the last 5 years, the annual visitation has averaged 90 thousand people, but in the mid-1980s the number of tourists was 200 thousand people per year.

The cave has attracted keen interest from naturalists for about 300 years. It has been dealt with in about 100

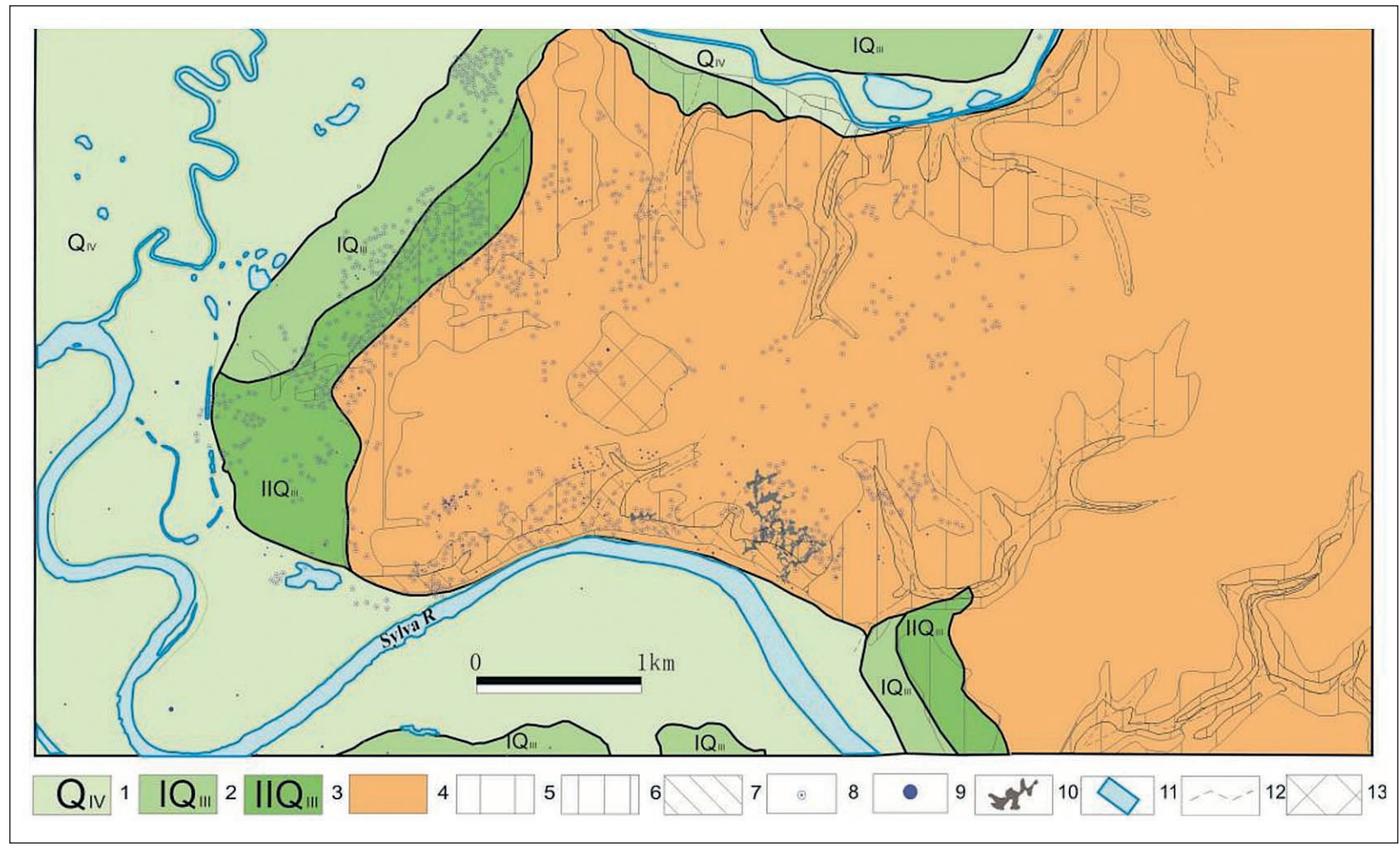

Fig. 2: Geological-geomorphologic scheme of Ledyanaya (Ice) Mountain massive. Legend: accumulative relief: 1 - modern alluvial low inclined plain of the low and high flood-plain of the Sylva and Shakva Rivers $\left(Q_{I V}, 4-12 \mathrm{~m}\right.$ above the lowest water level); 2 - the first above-flood-plain Upper Quaternary alluvial terrace, strongly denuded, with weakly expressed edge $\left(I Q_{I I I}, 15-25 \mathrm{~m}\right) ; 3-$ the second above-flood-plain Upper Quaternary alluvial terrace $\left(I I Q_{I I P}, 30-40 \mathrm{~m}\right) ; 4$ - Denudated relief: Pliocene-Quaternary flat upland of northern-west side of Ufa Plateau (up to $100 \mathrm{~m}$ ); downhill: 5 - 5-15 degrees, 6 - 15-25 degrees, 7 - >25 degrees; karst phenomena: 8 - dolines, 9 - sinkholes, 10 - contour of Kungur Ice cave; and others: 11 - rivers and lakes, 12 - thalweg of dry rivers, 13 - dump. 


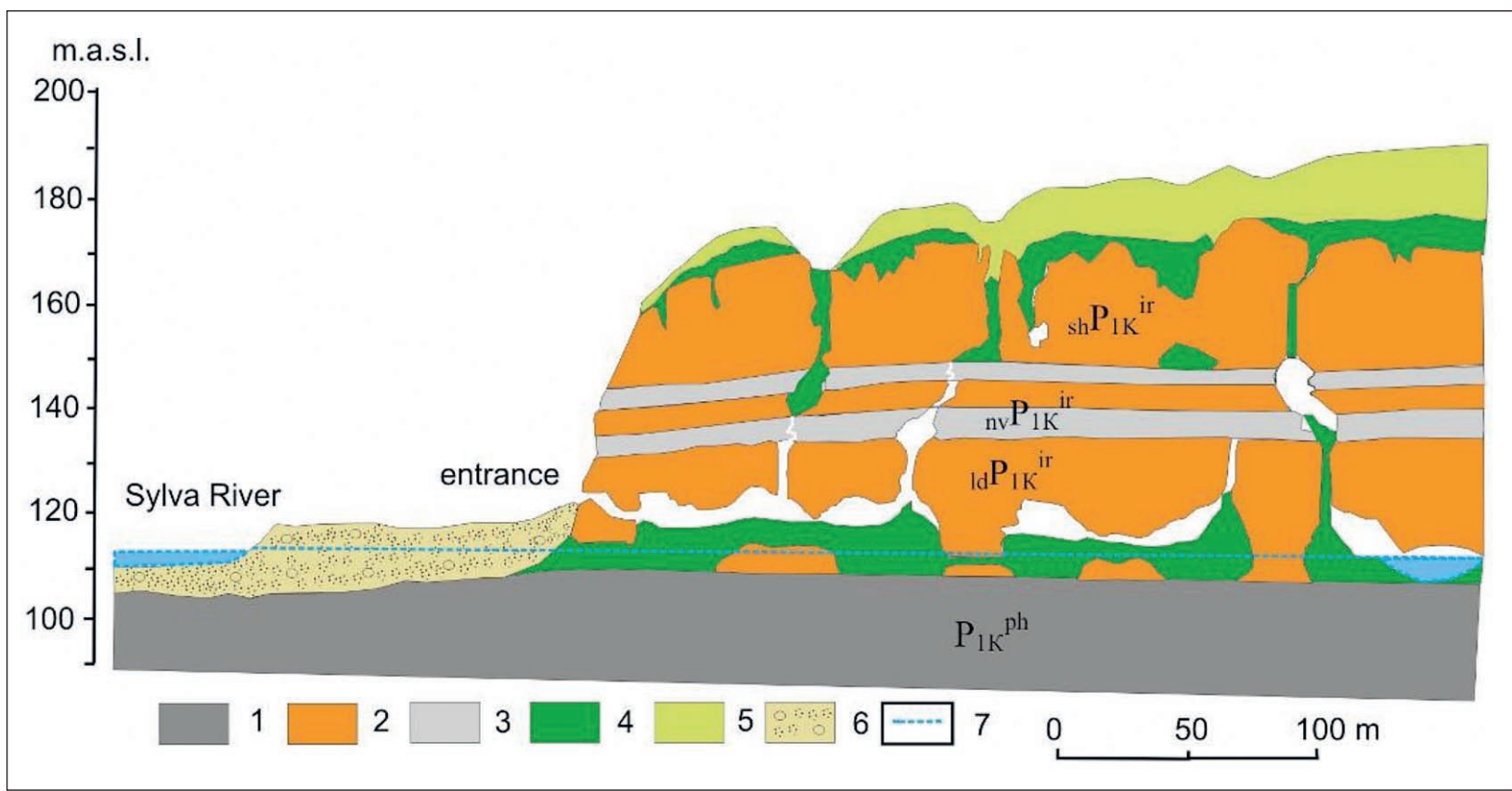

Fig. 3: Schematic geological section through Kungur Ice Cave gypsum massif. Legend: 1 - dolomites of Filippian horizon, 2 - sulphate layers of Irenian horizon, 3 - carbonate layers of Irenian horizon, 4 - collapse sediments and karst breccias, 5 - cover sediments, mainly clayey, 6 - alluvial deposits, 7 - level of underground water.

popular and over 500 scientific publications. Detailed geological, speleological, biological, etc. observations have been made there over the last 50 years.

The cave developed in an interfluvial gypsum-carbonate massif, which is closely connected hydraulically with the major River Sylva. Ledyanaya Gora (Ice Mountain) massif is a strongly karstified, plateau-like highland, rising 90-96 $\mathrm{m}$ above the riverbed. The karst relief of the interfluvial plateau is notable for its morphological diversity. The density of karst forms on Ledyanaya Gora ranges from 150-200 units per square kilometre in the watershed part of the plateau to 200-300 in the slope, and to over 500 in the edge part of the massif, including the cave. The massif and the cave are in all respects a model of conjugated evolution of surface and subsurface forms of carbonate and sulphate karst.

Unlike other well-known gypsum caves of Europe (in Germany, Spain, Italy, Poland and Ukraine), which formed in Triassic and Miocene gypsum, Kungur Ice Cave has developed in much older Lower Permian sulphate strata. Air circulation characteristics, cave morphology, and regional climate are conducive to the formation and accumulation of different ice forms in the cave, including perennial ice (underground ice mounds). Due to more severe climatic conditions in the region and peculiarities of the cave air exchange with the environment, underground ice persists in the cave all year round despite low hypsometric marks of the terrain $(120 \mathrm{~m}$ above sea level). This is in contrast with central Europe- an ice caves located from $969 \mathrm{~m}$ (Dobšinská Ice Cave in Slovakia) to 1,462 m-1,660 m above sea level (Eisriesenwelt in Austria, Scărişoara Cave in Romania and others).

There is a constant and rather energetic air exchange between the cave-massif and the outside environment. Its character is determined by the cave morphology and the nature of its connection with the surface. Location of horizontal cave entrances in the lower part of the slope and of craters on the massif surface, through which air goes out, produces a typical «chimney»-like pattern of air-flow through the massif. In the cold season, dense frosty air enters a warm cave, moves through it and, warming up, ascends through the cracks and organ tubes outside. In the warm season, when the outside temperatures $\left(10-25^{\circ} \mathrm{C}\right)$ are considerably higher than the cave air $\left(0-4{ }^{\circ} \mathrm{C}\right)$, cooler and dense air goes out of the entry openings, recouping the loss by drawing the air in from the surface down through the craters and cracks.

Descending into the cave through cracks and organ tubes, the outside air cools-down due to heat exchange with the cave walls and due to contact with ice formations. It is this pattern of air exchange with the outside environment that is favourable for the formation of permanent negative temperature in the entrance section of the cave, which accounts for underground ice formation in the winter-spring period and its preservation in the summer-autumn time. Due to its vicinity to the massif slope and inflow of cold air, the entrance section of the cave cools down considerably in the cold season, which 
enhances infiltration waters (ground and melt) freezing and atmospheric moisture sublimation. Consequently, subzero temperatures persist all year round in the permanently negative temperature zone.

The cave is an unusual environment for mineral formation, characterized by:

- mainly sulphate, less of carbonate; lithology of the cave host rocks: gypsum, anhydrite, dolomite, limestone and clay;

- abundant moisture: infiltration - rain, melt and ground - water, stagnant water of underground lakes, invading flood water with suspension, condensation moisture, etc.;

- cool $\left(0-+4{ }^{\circ} \mathrm{C}\right)$ and cold (below $\left.0{ }^{\circ} \mathrm{C}\right)$ thermal conditions in general;

- microclimatic inhomogeneity manifested in the air temperature zonal distribution, seasonal migration of microclimatic zones, and vertical stratification of weather conditions (Mavlyudov 1994);

- a considerable amount of underground ice, especially in the winter-spring time, and thermal instability of climatic conditions, particularly in low season, which brings about changes in the phase state of water;

- the entry (from the surface - through the sinks) of clastic, argillaceous and soil.

The aim of this study was to investigate the influence of microclimate on the material constitution of deposits in the grottos of Kungur Ice Cave. The objects of research were deposits in collapsed talus cones under organ tubes in different microclimatic zones of the cave (Fig. 4).

The cave is a system of horizontal passages with entrances at different altitudes. The lowest floor of the cave is situated at a level of about 111-112 $\mathrm{m}$ a.s.l., close to water level of the Sylva River. The cave is about $5.7 \mathrm{~km}$ long and is developed in an area of approximately $65000 \mathrm{~m}^{2}$, with a vertical range of $32 \mathrm{~m}$.

There are three microclimatic zones in the cave, which are distinguished by their temperature: 1) a zone with temperature permanently below $0{ }^{\circ} \mathrm{C}$ (cold zone); 2 ) a zone with temperature permanently above $0{ }^{\circ} \mathrm{C}($ warm zone); and 3) a zone with fluctuating temperature between freezing and thawing (transition zone). Cave air flows upwards in the cold season and downwards in the warm season. Upward (winter) air circulation in the cave begins in autumn when outside temperatures fall below $5^{\circ} \mathrm{C}$. Downward (summer) air circulation begins when outside temperature rise above $5{ }^{\circ} \mathrm{C}$.

In the cold zone, negative temperatures remain all year and are favourable for perennial ice formation. The permanent glaciation boundary is situated along the northern part of Krestovy Grotto and eastern part of Zapadny Grotto (at a distance of about $200 \mathrm{~m}$ from the entrance); while the seasonal glaciation boundary is situated along Morskoye Dno, Geologov and Smelykh Grottos (Fig. 5).

In the transition zone, the warmest period with temperatures $0{ }^{\circ} \mathrm{C}<\mathrm{T}<3{ }^{\circ} \mathrm{C}$ begins in April and lasts until October-November depending on when temperatures change from positive to negative outside the cave. In winter (December-March) seasonal ice forms in the transition zone in the Vyshka, Ruiny, Morskoye Dno, Smelykh and Grozny Grottos. We also need to add to the transition zone boundary parts of perennial ice in the Scandinavsky and Polarny Grottos, but warm period here is much shorter - only two to three months (September - November).

The cave protected area and Druzhby Narodov, Romantikov, Dlinny, Colisei and other grottos are located in the neutral zone of the cave with virtually constant temperatures about $5-6{ }^{\circ} \mathrm{C}$ (Fig. 5).

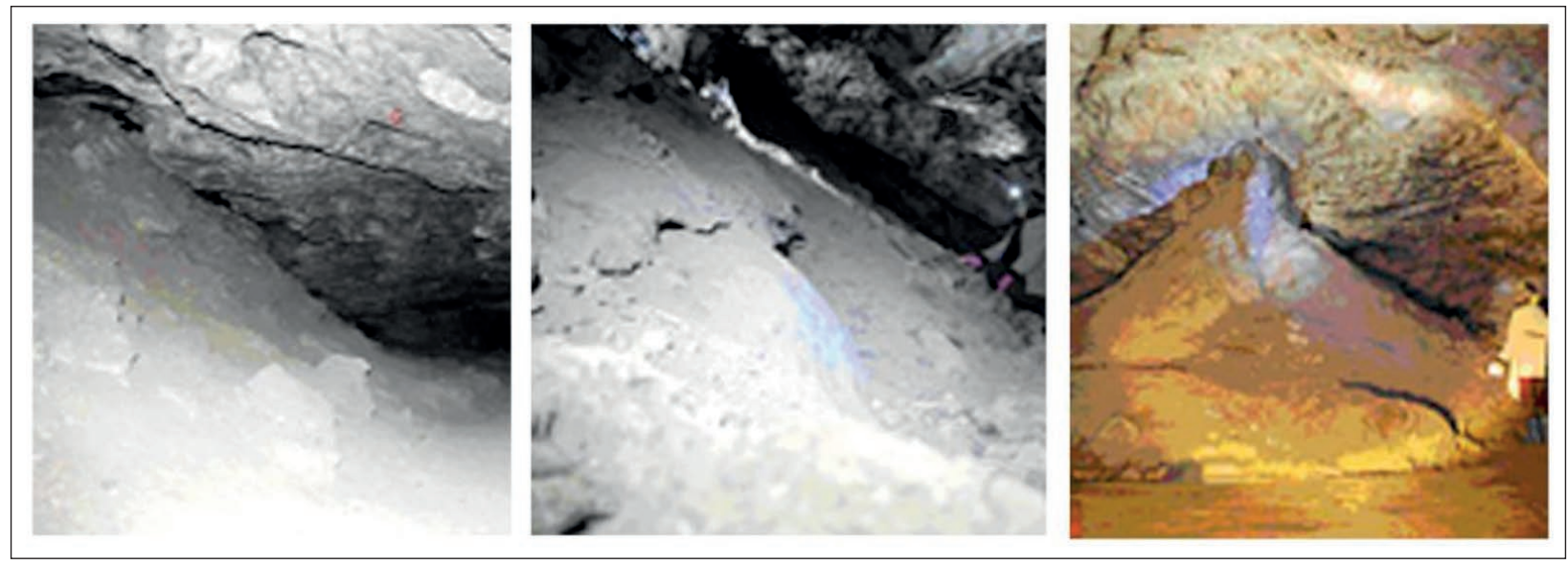

Fig. 4: General view on the slide-rocks under organ tubes from different microclimatic zones (on the left - cold zone of permanent temperatures below $0^{\circ} \mathrm{C}$; in the centre - transition zone; on the right-warm zone with virtually constant temperature s above $0{ }^{\circ} \mathrm{C}$ ). 


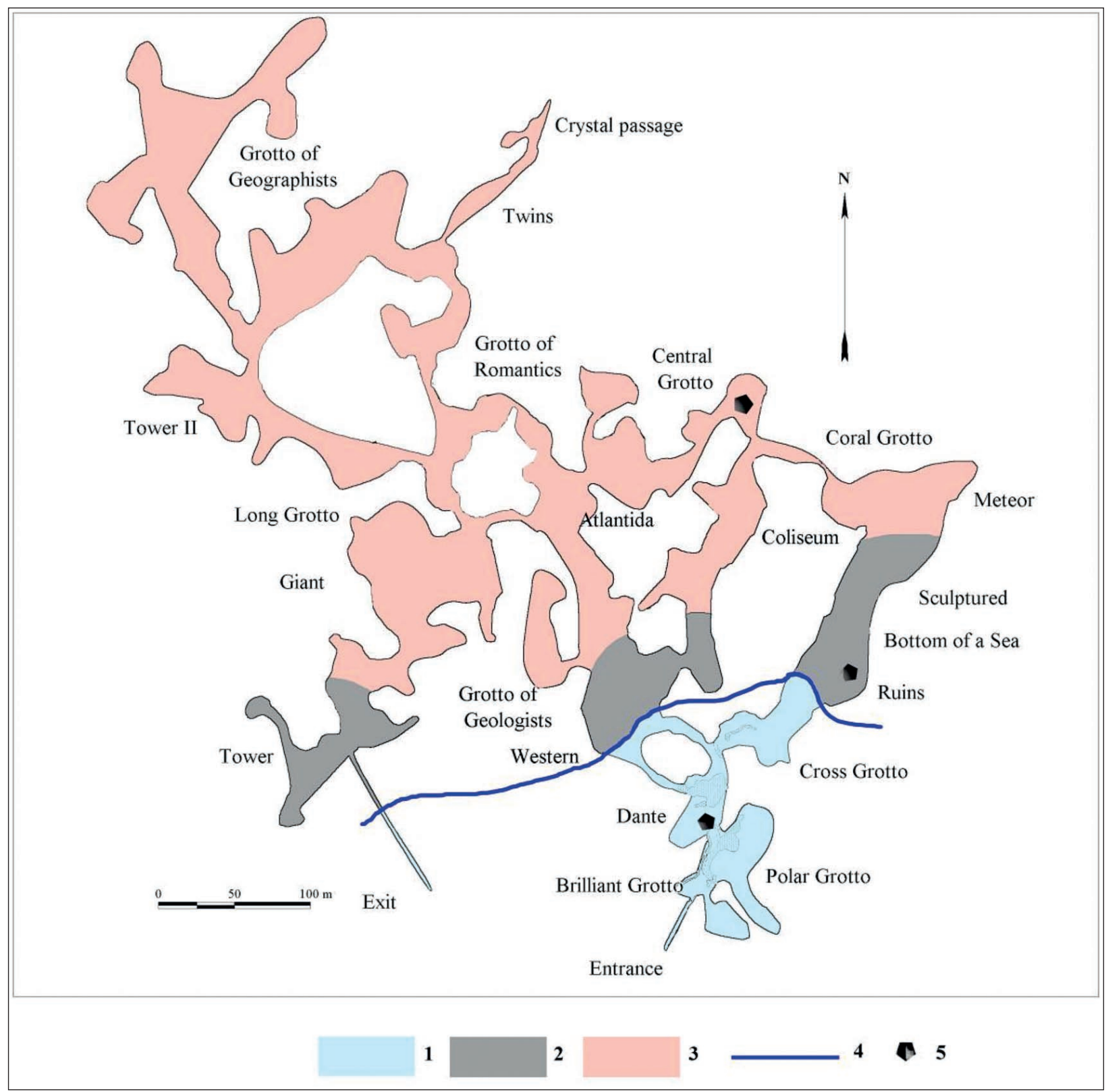

Fig. 5: Location of sampled rocks in different climatic zones in the Kungur Ice Cave: 1 - cold zone of permanent temperatures below $0{ }^{\circ} \mathrm{C}$; 2 - transition zone; 3 - worm zone with virtually constant temperatures; 4 - perennial glaciation boundary; 5 - sampling points.

\section{METHODS}

Continuous recording of temperature changes was held for 3 to 5 year period at the stationary point in order to characterize the effect of cave micro-climatic conditions on the formation of underground water and cave deposits. Methods for studying mineral and chemical composition are used in the study of samples of cave deposits.
To study the morphology of crystals and the mineral composition of rocks the polarizing microscope "Carl Zeiss" connected to a computer was used. Study of morphology and chemical composition was performed using the scanning electron microscope VEGA 3 LMH with a system of X-ray energy dispersive microanalysis INCA Energy 350 / X-max 20 in the Mining Institute of 
Tab. 1: General Characteristic of the Collapsed Slide-Rock Cone Deposition Samples under Organ Tubes.

\begin{tabular}{c|l|l|c|l|l}
\hline № & Climatic zone & Location & Weight $(\mathrm{kg})$ & Moisture & Features \\
\hline 1 & $\begin{array}{l}\text { Cold zone (permanent tmperatures } \\
\left.\text { below } 0{ }^{\circ} \mathrm{C}\right)\end{array}$ & $\begin{array}{l}\text { Poliarny-Dante } \\
\text { passage }\end{array}$ & 7 & Dry & $\begin{array}{l}\text { Organic substance material, friable and } \\
\text { light }\end{array}$ \\
\hline 2 & $\begin{array}{l}\text { Transition zone (negative } \\
\text { temperatures in winter and positive } \\
\text { in summer) }\end{array}$ & $\begin{array}{l}\text { Krestovy-Ruiny } \\
\text { passage }\end{array}$ & 14 & Moist & Heavy \\
\hline 3 & $\begin{array}{l}\text { Warm zone (the same temperature } \\
\text { in the cave and karst massif) }\end{array}$ & Efirny Grotto & 9 & Moist & $\begin{array}{l}\text { grooves on the talus surface along } \\
\text { which water drains from the organ tube }\end{array}$ \\
\hline
\end{tabular}

UB of RAS (analysts are E.P. Chirkova and O.V. Korotchenkova).

Accumulative cones in the cave are situated under the mouths of organ tubes. These cones are composed of: karst massif dissolution products (sulphate and carbonate rock debris and clay) and material from the PlioceneQuaternary sediments covering mountain above the cave (clays, loams, detritus, pebbles etc). Three talus cone deposits located below organ tubes were chosen for study (Fig. 5): the first in Poliarny-Dante passage (cold zone); the second in Krestovy-Ruiny passage (transition zone); and the third in Efirny Grotto (warm zone).

Samples of 8 litres volume were collected in July 2009 from the talus surfaces. The general characteristics of the samples are given in Table 1. The samples were wet screened and divided into the following classes following GOST (1979): clay $(<0.1 \mathrm{~mm})$, sand $(0.1-1 \mathrm{~mm})$, fine gruss $(1-5 \mathrm{~mm})$, coarse gruss $(5-10 \mathrm{~mm})$, sandy-gravel $(5-10 \mathrm{~mm})$ and coarse gravel $(10-100 \mathrm{~mm})$.

\section{RESULTS}

The lithological composition of debris and their quantity was determined for each size class (Fig. 6).

Due to inertness of material transformation processes in the cold zone, the grainsize distribution of these deposits can be viewed as an initial or reference distribution. Compared with deposits in the transition zone, the proportion of finer-grained fractions is increased and the proportion of coarse debris is decreased. In the warm zone, the proportion of coarse debris increases and the proportion of finer-grade deposits decreases. In the transition zone, changes to the grainsize distribution are related to frost weathering (disintegration), while in the warm zone they result from material being washed out by draining water.

Study of the lithological composition of the coarsedetritus $(>1 \mathrm{~mm})$ fraction showed that the talus in all microclimatic zones is composed of debris from the following rocks: pelitomorphic dolomite, oolitic calcareous dolomite (calcined and blasted to different degrees), calcite breccias and gypsum (Fig. 7).

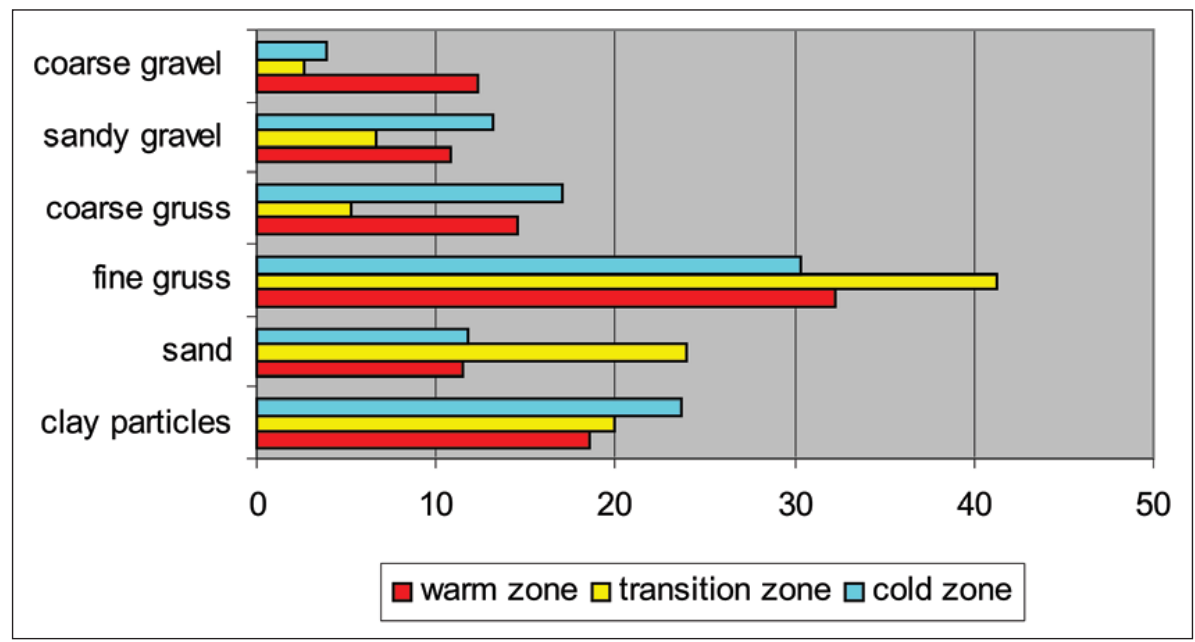

Fig. 6: Proportion of debris fractions in the taluses from different microclimatic zones. 


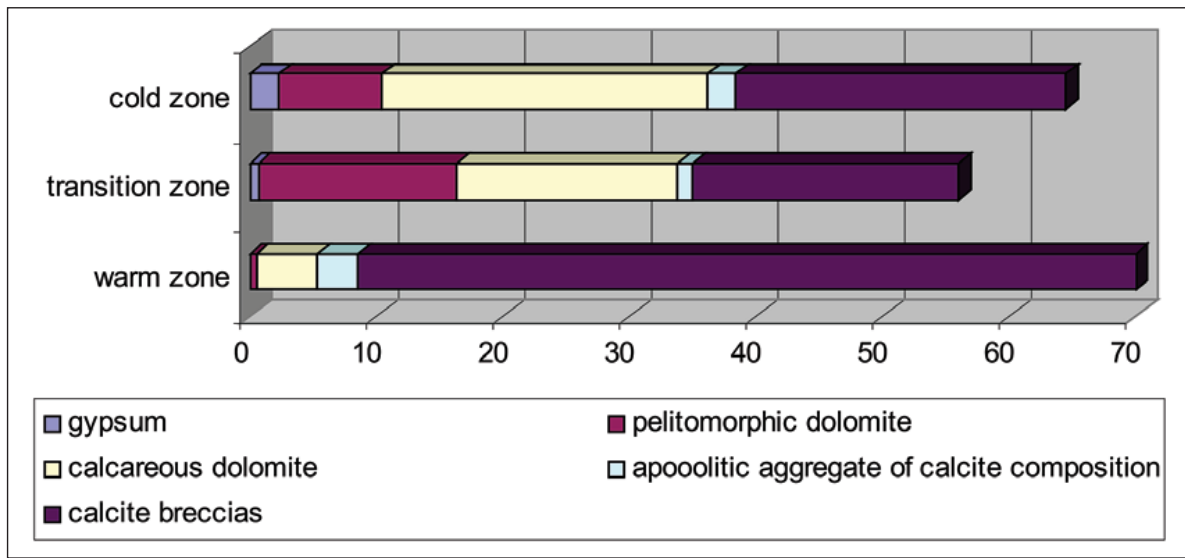

Fig. 7: Lithological composition of coarse-detritus fraction in the taluses of different microclimatic zones (difference from $100 \%$ is due to fine grain fraction).

Dolomitic rocks are derived from the Nevolinskaya geological unit, while breccia is derived from resedimentation of carbonate material in intermediate cavities in the karst massif. Gypsum was only found in the cold and transition zones and could have been derived from the Shalashninskaya, Nevolinskaya or the Ledianopescherskaya geological units.

The absence of sulphate rocks in the warm zone and their lower content in the transition zone reflects the activity of the dissolution processes in the talus itself. Irregular variation in the quantity of carbonate rocks (breccias and dolomites) can reflect different hypergene transformations of rocks in the upper part of the karst massif.

Quantitative mineralogical analysis of the sand fraction in the talus often showed the occurrence of trace $(<2 \%)$ of quartz, flint, argillite and ferric hydroxide. Fragments of calcite breccias and dolomite oolites were prevalent (Fig. 8). Two varieties of sulphate occur - finegrained gypsum (alabaster) debris and idiomorphic gypsum crystals.

The absence of pelitomorphic dolomite may indicate its transition into the pelitic (clay) fraction, with a loss of the sand fraction during weathering. The presence of gypsum crystals in the transition zone may indicate that neogenic gypsum individuals are formed during the dissolution of fragmental alabaster.

Except processes of dissolution and removal of the material, its deposition and accumulation takes place in karst massifs. Problems of transformation of carbonate massifs are widely discussed in the works of Russian and foreign researchers. Processes occurring in the carbonate-sulphate massifs are more complex and today virtually unknown. There are unique regional characteristics of geological evolution of the karst strata in the areas of carbonate-sulphate deposits distribution. The relevance of studying the processes of transformation of interbedded carbonate-sulphate rocks section «Ice Mountain» emphasizes the fact that it is part of a complex of stratotype outcrop Kungurian stage of the Permian system.

A considerable variety of environments and factors of mineralization in Kungur Ice Cave's grottos is determined by microclimatic zoning, manifested in zonal distribution of air temperature, seasonal migration of microclimate boundaries, change phase states of water.

Sediment of accumulation cones (talus) at the mouths of organ tubes are represented by fragments of sulphate and carbonate rocks with clay core. Carbonate

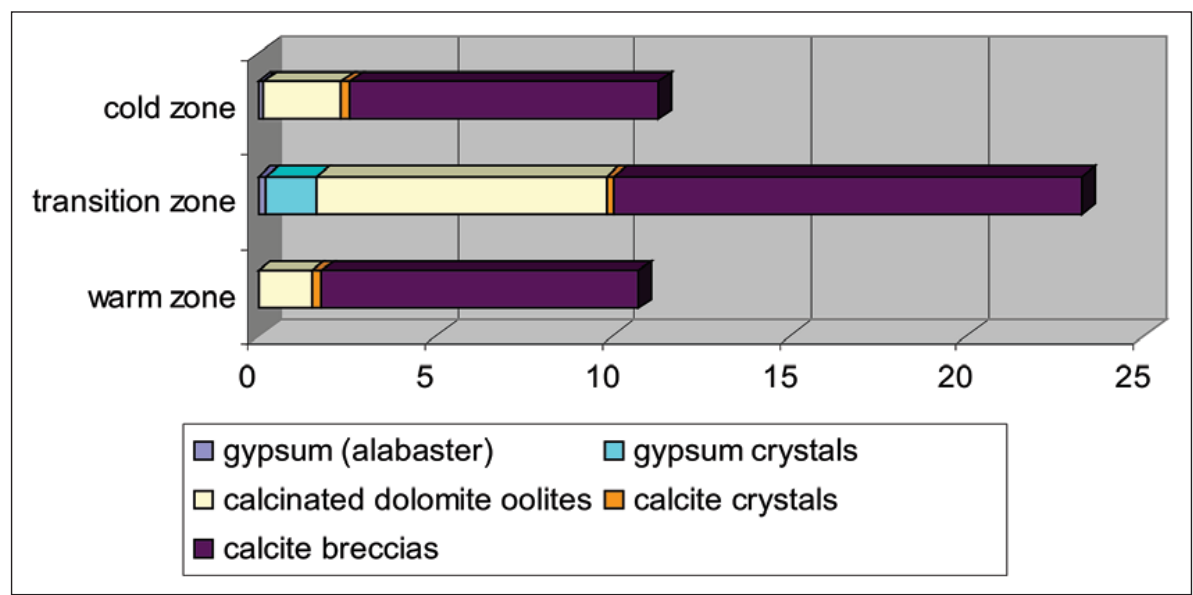

Fig. 8: Lithological and mineralogical composition of fine clastic (sand) fraction. 
Tab. 2: Occurrence and morphological characteristic of minerals and aggregates in sand fraction.

\begin{tabular}{|c|c|c|c|c|}
\hline \multicolumn{2}{|c|}{ Minerals, aggregates, debris and their forms } & \multicolumn{3}{|c|}{ Microclimatic zones } \\
\hline & & \multirow{2}{*}{$\begin{array}{l}\text { Warm Efirny } \\
\text { Grotto }\end{array}$} & \multirow{2}{*}{$\begin{array}{l}\text { Transition Passage } \\
\text { between Krestovy } \\
\text { and Ruiny Grottos }\end{array}$} & \multirow{2}{*}{$\begin{array}{l}\text { Cold } \\
\text { Passage between } \\
\text { Polarny and Dante } \\
\text { Grottos } \\
+\end{array}$} \\
\hline Gypsum & $\begin{array}{l}\text { Alabaster debris of } \\
\text { Ledianopeschernaya geological unit }\end{array}$ & & & \\
\hline & Regenerated alabaster & & + & + \\
\hline & Gypsum crystals & & + & + \\
\hline & $\begin{array}{l}\text { Aggregates and complex aggregates } \\
\text { including split ones }\end{array}$ & & + & + \\
\hline & Concretions ('hedgehogs') & & + & \\
\hline & Crystal crusts & & + & \\
\hline & Selenite & & + & \\
\hline & 'Roses' & + & & \\
\hline Celestine & Crystals & & + & \\
\hline \multirow{7}{*}{$\begin{array}{l}\text { Carbonate oolites of } \\
\text { Nevolinskaya geologic } \\
\text { unit }\end{array}$} & Pelitomorphic calcite-dolomite & + & + & + \\
\hline & With leached core & + & + & + \\
\hline & With drusy calcite core & & + & + \\
\hline & Recrystallised calcitised & + & + & + \\
\hline & Regenerated & + & + & + \\
\hline & Rhodochrositic & + & + & + \\
\hline & Sideritic & & & \\
\hline \multirow[t]{6}{*}{ Calcite } & Off-white opaque & +++ & + & +++ \\
\hline & Yellowy and colourless & ++ & ++ & ++ \\
\hline & Colourless sharp rhombohedral & + & + & + \\
\hline & Prismatic with split vertex & & & + \\
\hline & Columnar stringers & & & + \\
\hline & Aggregates, crusts & & & + \\
\hline \multirow[t]{3}{*}{ Argillite fragments } & Unmodified & + & & + \\
\hline & Leached & + & & + \\
\hline & Ironed & + & + & + \\
\hline Manganese hydroxides & Leather coat, buds, solid aggregates & + & + & + \\
\hline
\end{tabular}

and sulphate debris in talus comes from Ledyanopescherskaya and Nevolinskaya geological units. Some debris has been recrystallized in karst array, and then moved by organ tubes to the cave from the upper horizons, another group of minerals was formed in the studied talus.
Ontogenic investigation demonstrated a large variety of mineral individuals and aggregates (Tab. 2) which formation is connected with processes both in the karst massif and the talus itself.

\section{MINERAL ASSOCIATIONS FORMED IN THE KARST MASSIF}

Debris of aggregates connected with alteration of carbonate rocks of Nevolinskaya geological unit are referred to associations of minerals formed in the karst massif. They are found in talus in all climatic zones. The initial substrate was oolitic and pelitomorphic dolomite.

Presence of transitional forms between unaltered and secondary rocks allows us to assume that gradual leaching of magnesium (dolomitic) component and formation of delicate, crusty hollow-cored aggregates in place of oolitic sub-individuals or pelitomorphic aggregate debris, took place during the infiltration of vadose waters.

Reconstructed stages of transformation seem to be: pelitomorphic oolitic $\rightarrow$ calcinated dolomite oolites with 


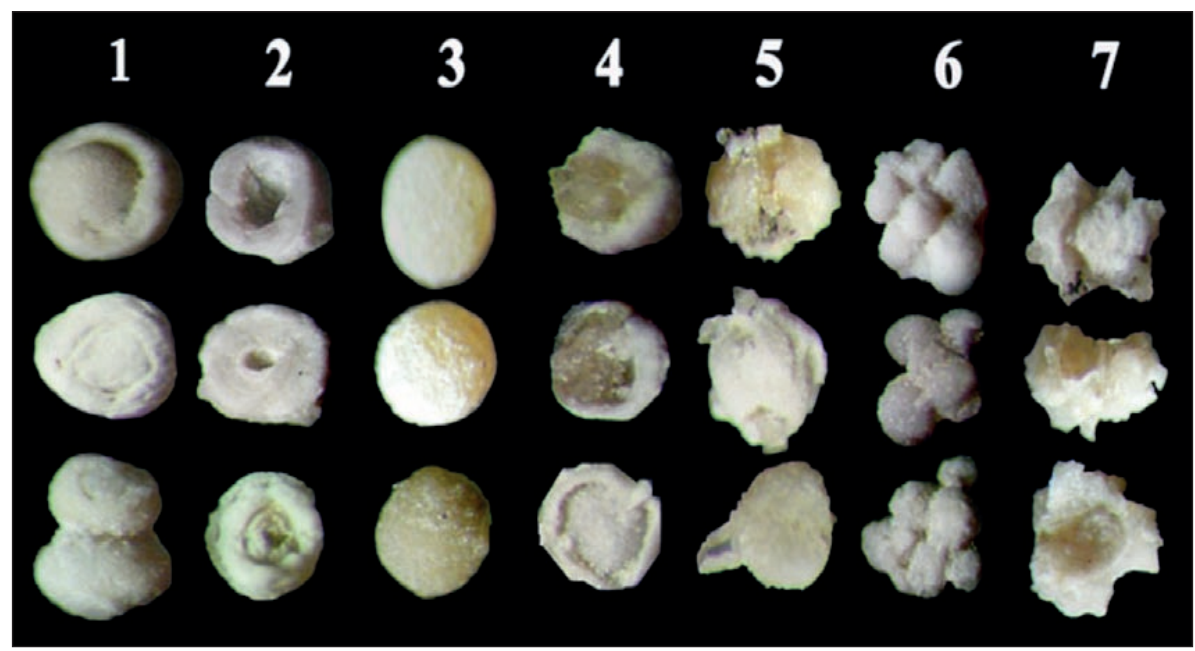

Fig. 9: Stages of successive transformation of oolites $(0.1-1 \mathrm{~mm}$ in size): 1 - initial calcinated dolomite oolites; 2 - leached-core oolites; 3 - translucent recrystallized oolites of calcite composition; 4 - with a drusy-secretional calcite core; 5 - oolites covered with calcite crystals; 6 - aggregates with a neogenic calcite cement; 7 - fragments of cavernous apooolitic aggregate of calcite composition.
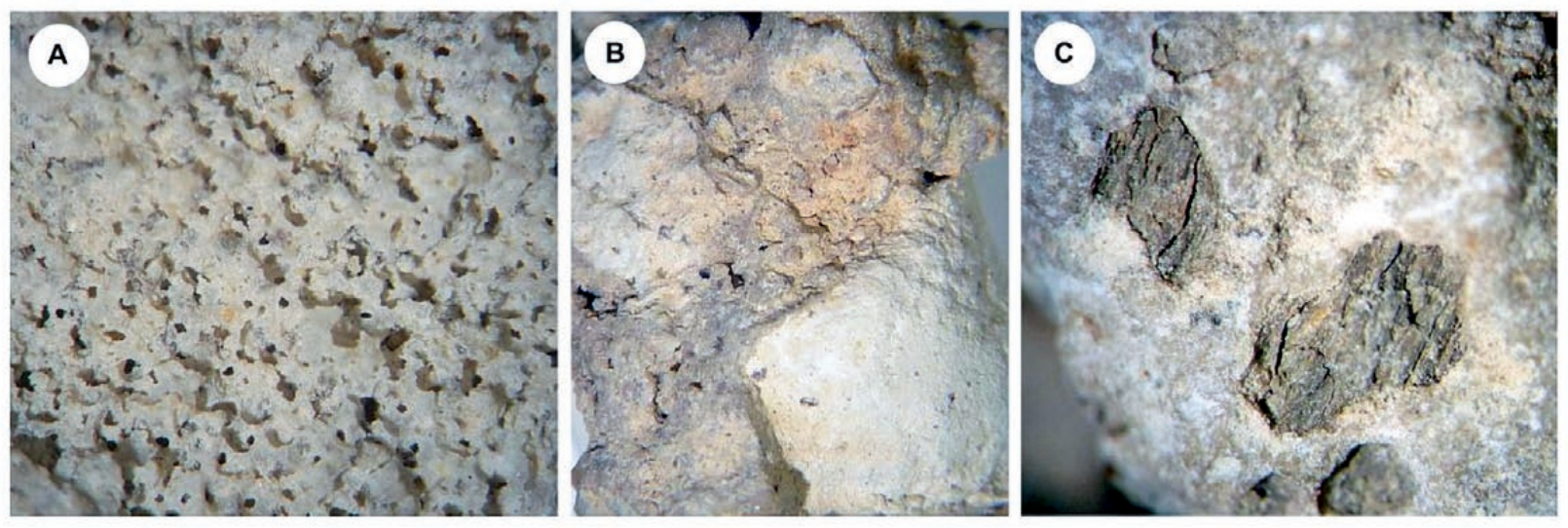

Fig. 10: Calcite aggregate debris (1-10 cm in size) formed in the karst massif: A - cavernous apooolitic aggregate; B, C, - breccias with pelitomorphic dolomite and argillite debris.

a leached-core $\rightarrow$ oolites with a drusy, secretional calcite core $\rightarrow$ cavernous, drusy calcite aggregate (Fig. 9).

Along with cavernous, drusy calcite aggregates, calcite breccias were also formed in the massif. Pelitomorphic dolomite and argillite occur as fragments in breccia (Fig. 10). In some breccias rock debris is completely leached, this may indicate that they spent a long time in the infiltration zone. The occurrence of mechanical wear (rounding) traces on the debris of calcite-cemented breccias reflects transport over a long distance from the massif to the cave through repeated collapse (Fig. 11).

Formation of pseudomorphs after manganese calcite, rhodochrosite and siderite on the base of oolite sub-individuals indicates that during general leaching of

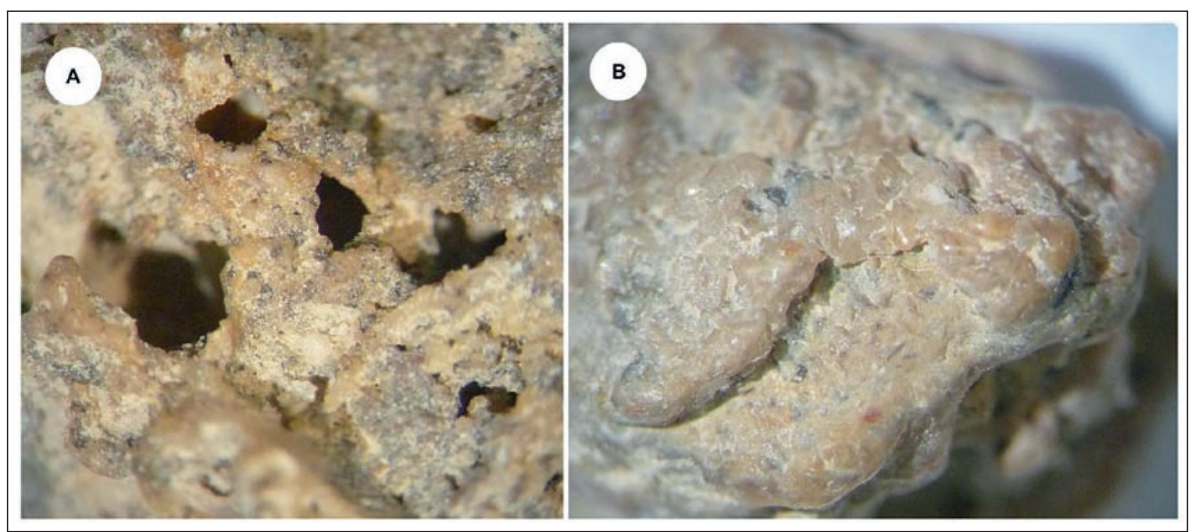

Fig. 11: Breccias (1-10 cm in size) with leached debris and traces of mechanical transport. 


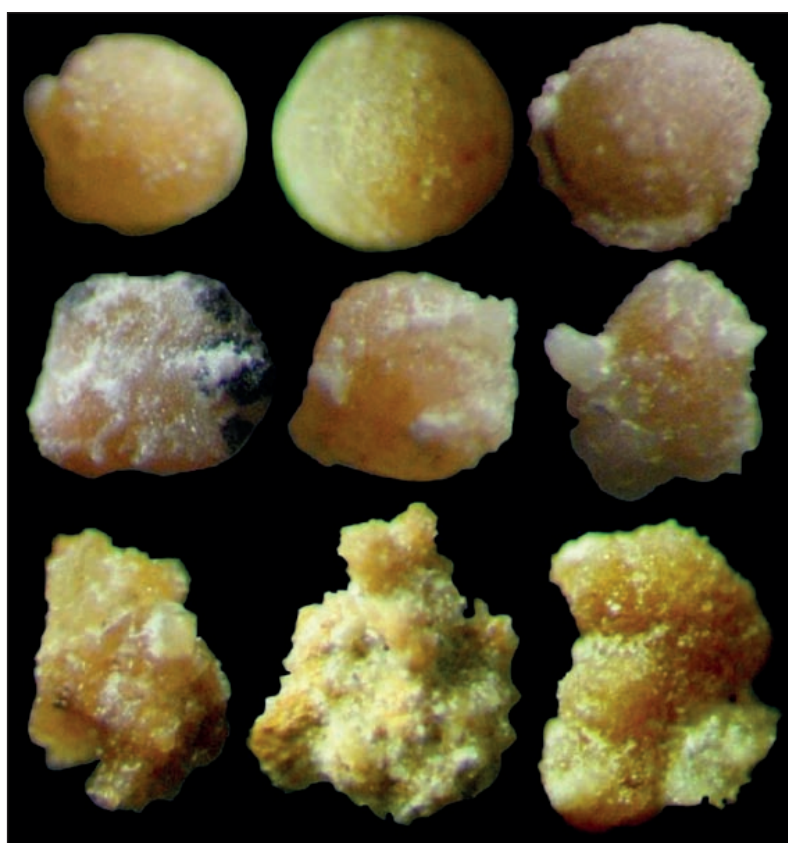

Fig. 12: Dolomitic oolites (0.1-1 $\mathrm{mm}$ in size) substituted by rhodochrosite (top and middle row) and overgrown by siderite. carbonate rocks, local super saturation occurred resulting in ionic substitutions such as: calcite $\mathrm{CaCO}_{3} \rightarrow$ manganese calcite $(\mathrm{Ca}, \mathrm{Mn}) \mathrm{CO}_{3} \rightarrow$ kutnogorite, $\mathrm{CaMn}\left(\mathrm{CO}_{3}\right)_{2}$ $\rightarrow$ rhodochrosite $\mathrm{MnCO}_{3}$, and also; calcite $\mathrm{CaCO}_{3} \rightarrow$ siderite $\mathrm{FeCO}_{3}$ (Fig. 12). During further transformation in the presence of oxygen, iron and manganese compounds were transformed into sulphates (jarosite) and hydroxides.

Presence of free oxygen resulted in the oxidation of iron and manganese compounds and the formation of reniform and earthy hydroxide excretions (Fig. 13). It has been noted that during iron oxidation, laminated silicates in argillite gradually transformed into argilloocherous masses (Fig. 14).

Thus, sulphate ion saturated infiltration water caused not only leaching of the carbonate layers, but also the transformation of their mineral content (dedolomitisation) and of their structural and textural features. Thereby pore spaces were enlarged and the massif was prepared for the formation of karst voids, particularly organ tubes.

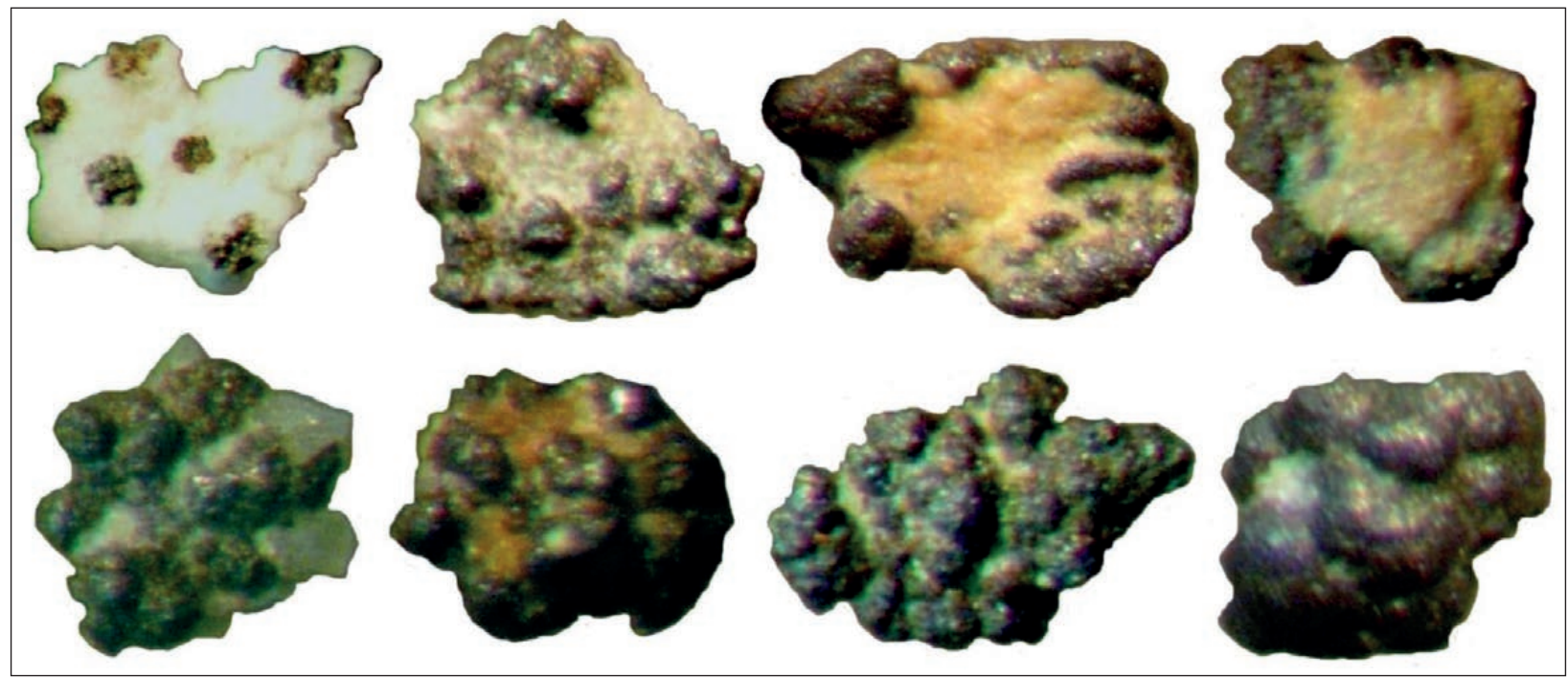

Fig. 13: Fine coat and reniform manganese hydroxide aggregates on the rock debris (0.1-1 $\mathrm{mm}$ in size) of different content.

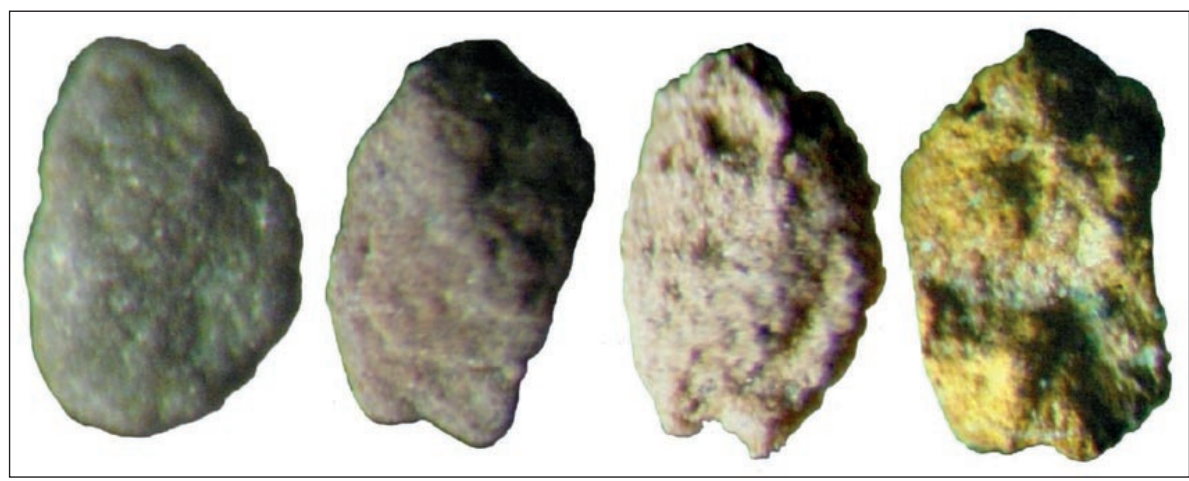

Fig. 14: Series of successive transformations and limonitization of an argillite fragment $(0.1-1 \mathrm{~mm}$ in size). 


\section{DISCUSSION ON MINERAL ASSOCIATIONS FORMED IN THE TALUSES IN DIFFERENT MICROCLIMATIC ZONES OF THE CAVE}

As shown above, the talus is composed mainly of carbonate material, with sulphate debris only remaining in transition and cold zones. Mineralogical analysis of the material in warm zone showed sulphates only occurring as solitary concretions of fine lamellar crystals called gypsum roses (Fig. 15). Their delicate structure and fragility leads us to believe that they formed within the talus itself, probably from previously dissolved alabaster debris.

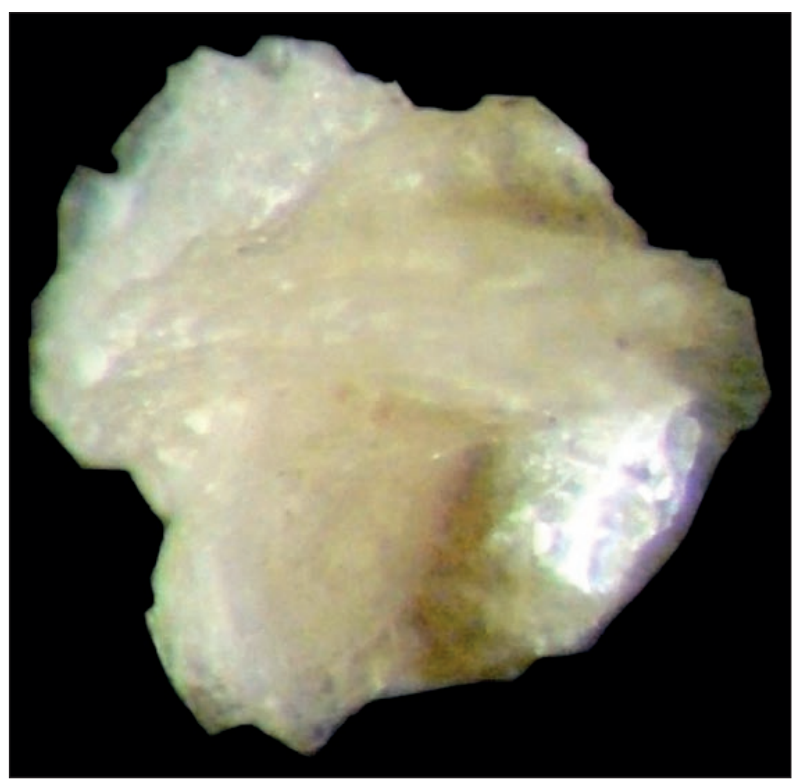

Fig. 15: Gypsum rose $(0.7 \mathrm{~mm}$ in size) from the warm zone (Efirny Grotto).
In the talus from cold zone, gypsum occurs mainly as irregular alabaster debris that makes up about 2.3 volume per-cent. Along with the debris, there are fine $(0.1-0.5 \mathrm{~mm})$ individuals and aggregates attributed to cryogenic processes as described by Andreichuk (1989), Andreichuk \& Galuskin (2001) and Tchaikovsky \& Kadebskaya (2009). These occur as split-individuals, skeleton and plain-face crystals or joints like larkspur (Fig. 16). We also found complex aggregates, different areas of which reflect change of fast imperfect growth characterized by being a muddy white colour, plainfaced, colourless and transparent. Such change implies short-run warming episodes.

In the transition zone, along with unmodified debris of granular gypsum (alabaster) we found aggregates recrystallized to different degrees; ranging from mediumgrained to concretion-like forms covered by drusy crust (Fig. 17). Were also found thin, foliated split and skeleton crystals associated with cryogenesis, as well as numerous plain-face crystals with a different habit, formed at temperatures above $0{ }^{\circ} \mathrm{C}$ (Fig. 18). None of these individuals showed traces of mechanical wear, indicating that they formed in the talus itself. Prismatic celestine crystals with uneven corroded surface were less common. Thus, in warm zone where vigorous dissolution of the sulphate material took place; there was virtually no formation of new gypsum.

In the cold zone a lot of gypsum debris occurs, resulting from suppression of the dissolution processes.
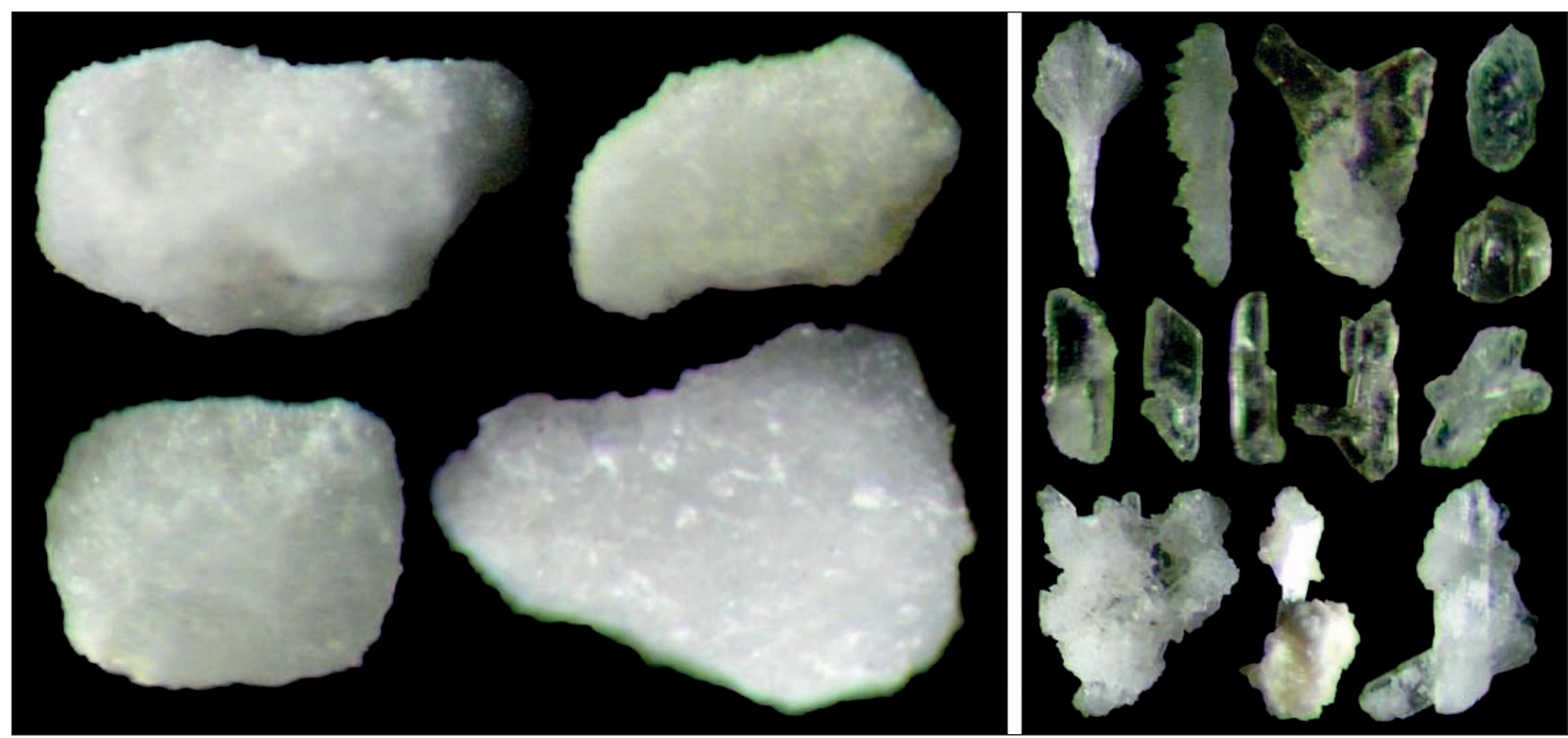

Fig. 16: Alabaster debris (0.1-1 $\mathrm{mm}$ in size) and cryogenic gypsum formations (0.1-0.5 $\mathrm{mm}$ in size) from the cold zone talus. 

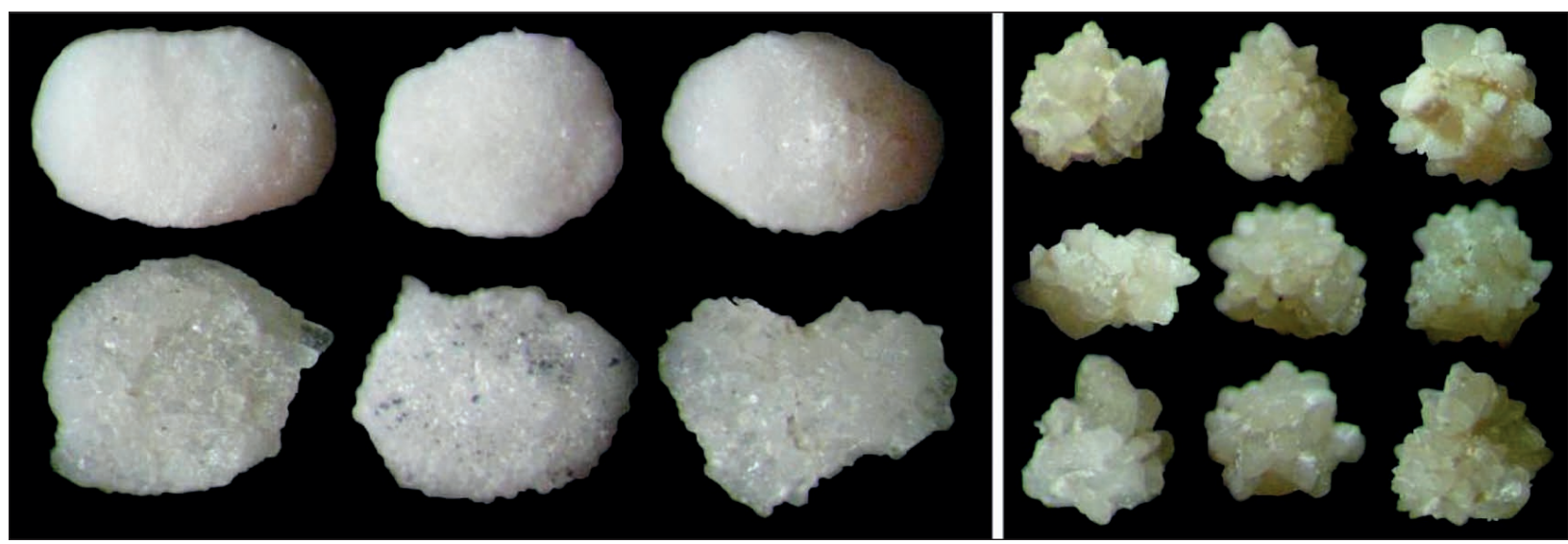

Fig. 17: Gypsum debris (0.1-1 $\mathrm{mm}$ in size) and products of their particular or complete recrystallisation from the transition zone talus.
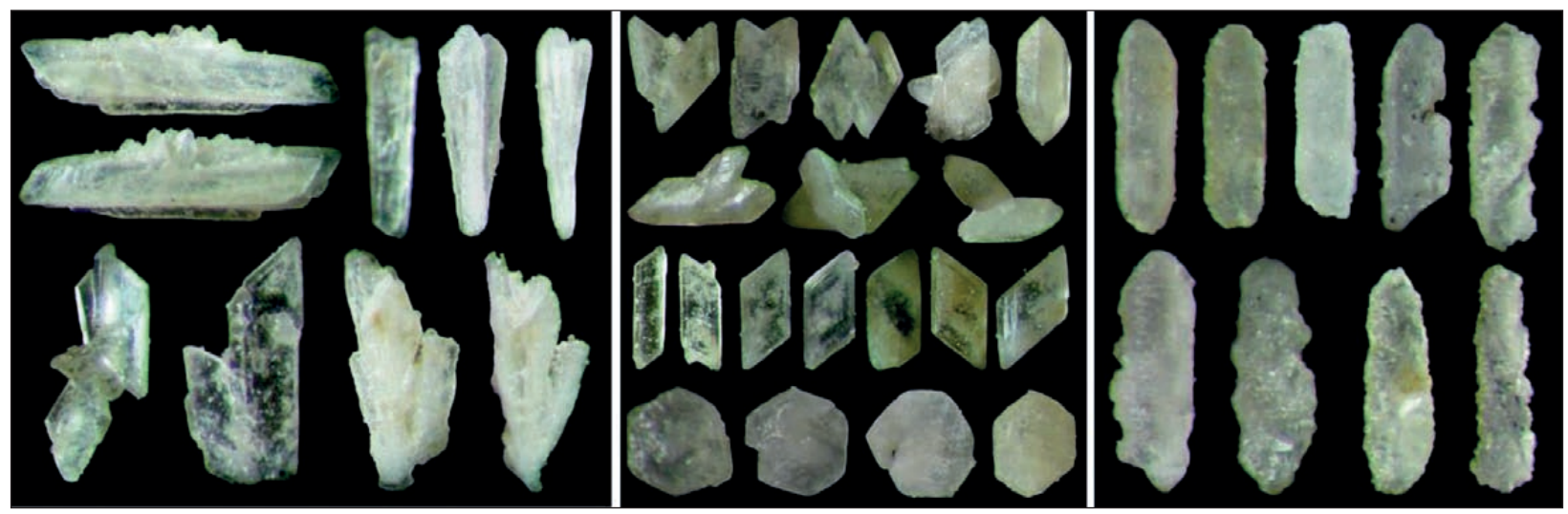

Fig. 18: Neogenic gypsum (cryogenic and usual, 0.1-1 $\mathrm{mm}$ in size) and celestine from the transition zone talus.
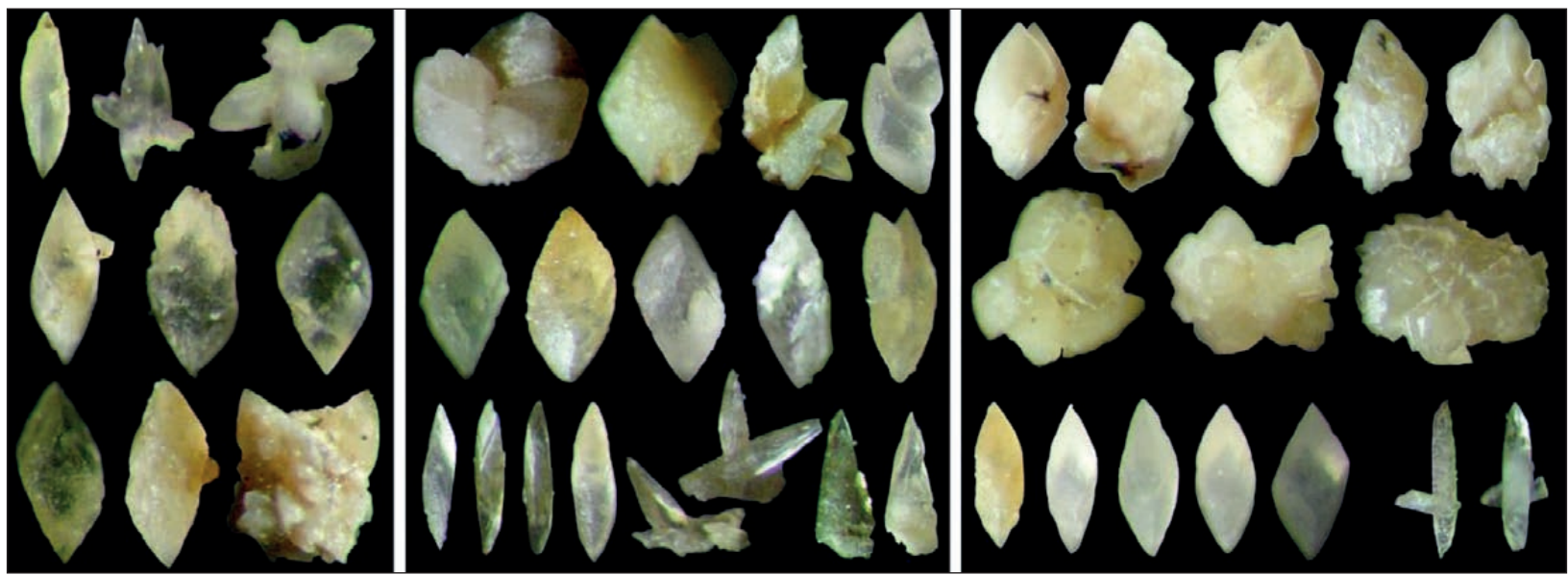

Fig. 19: Calcite morphology (0.1-1 $\mathrm{mm}$ in size) from cold, transition and warm zones.

Authigenic forms are presented only by a few fine cryogenic deposits, which may result from ice evaporation. In the transition zone, only a small amount of original alabaster debris has survived. It is mostly recrystallized. Along with cryogenic forms, there are different morphological types of gypsum. These indicate that considerable temperature fluctuations and probably a degree of solution saturation also occurred.

Overall, analysis of calcite forms showed a similar range of crystal morphologies. In all samples three types of rhombohedral crystals were found: relatively isometric cream opaque crystals, sharper colourless-yellowish 


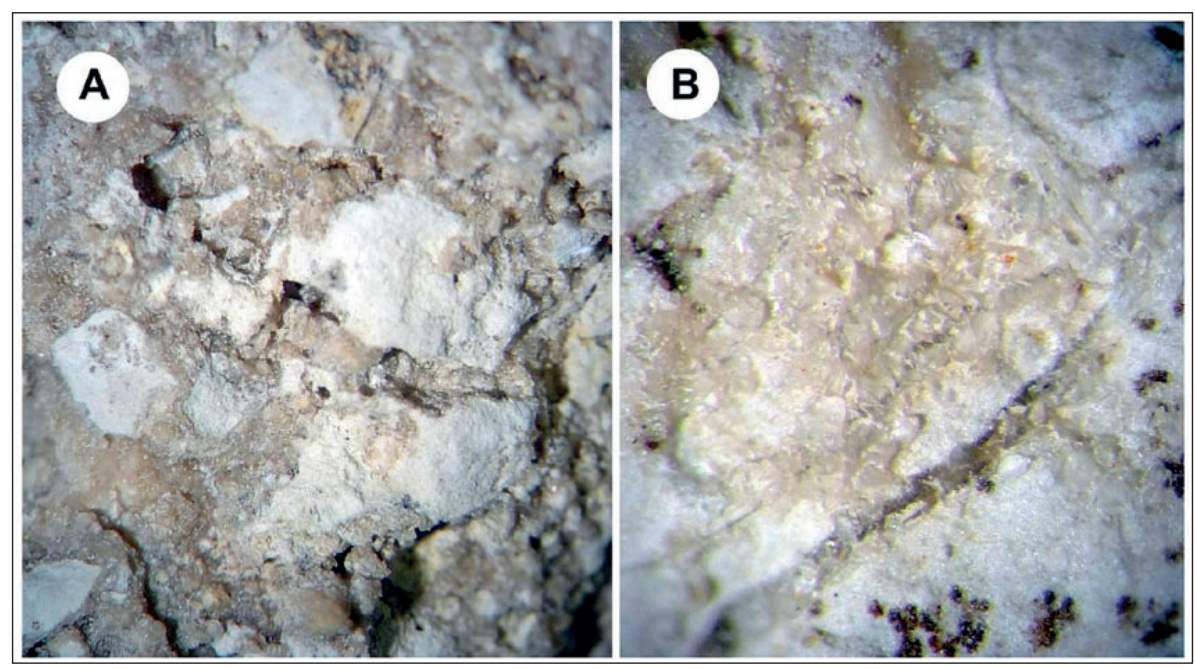

Fig. 20: General view and details of morphology of neogenic breccias (debris $1-5 \mathrm{~cm}$ in size) cemented and overgrown by calcite crystals from the transition zone.

crystals and sharp colourless crystals. In the cold zone a minimal amount of neogenic calcite occurs along with solitary individuals with a split (hackly) surface (Fig. 19). In the warm zone besides separate crystals and concretions, more complex concretionary aggregates were observed and in the transition zone - lithified parts of the talus (breccias) are cemented by calcite cement (Fig. 20).
Thus, the cave climate does not have strong influence on the diversity of morphological types of calcite and mainly affects the intensity of mineral formation. In the cold zone, these processes are reduced and in the transition zone, they cause appearance not only of separate crystals, but also of breccias, making them rockforming processes.

\section{CONCLUSIONS}

Thus, infiltration water, saturated with sulphate ion, leads not only to carbonate packs leaching, but also to the transformation of mineral (dedolomitization) composition and structural and textural features. In carbonate packs an increase of pore space where infiltration water can accumulate takes place. On the borders of carbonate and sulphate rocks hydration of anhydrite and preparation to the formation of karst caverns actively takes place. Infiltration of water results in a significant transformation of structure and composition in carbonate rocks, manifested in form of lime component leaching, dolomite recrystallization and redeposition of elements previously being in form of an isomorphous impurity, in form of its own mineral phases (siderite, celestite, barite, iron and manganese hydroxides, and et al.). The presence of iron and manganese minerals with varying degrees of oxidation (carbonates and hydroxides) indicates nonequilibrium conditions of change of the original rocks.

In spite of the same initial chemical composition of the fluids formed during infiltration through carbonatesulphate massif, newly formed minerals differences in morphology associated with various facial-climatic conditions and mechanisms of supersaturated solution, were revealed for different climate zones in the cave and the weathering crust.

Study of material constitution of collapsed talus deposits under organ tubes that expose virtually all of the karst rock sequence above Kungur Ice Cave allow us to distinguish two major stages in their transformation.

The first stage of transformation occurred in the karst massif long before the cave was formed. Transformation processes were timed to dolomitic rock layers localized in the gypsum- anhydrite section. These rocks underwent selective leaching and recrystallization that was accompanied by ion exchange reactions; dedolomitisation, rhodochrositation and sideritisation.

As a result, highly porous apooolitic calcitites and breccias with calcite cement were formed. These processes are thought to precede and prepare the karst massif for the formation of voids and in particular of organ tubes.

After the disintegrated material collapsed into Kungur Cave, it underwent further transformation in different microclimatic situations. In the cold zone, transformation of carbonates and sulphates was reduced. The maximum quantity of alabaster debris occurred here 
and neogenic gypsum occurred as cryogenic individuals formed by sulphate and calcite waters freezing.

In the warm zone, clastic sulphate material was completely dissolved and authigenic solitary gypsum roses were precipitated. In the transition zone, some of the dissolved clastogene gypsum was converted cryogenic and multiform habit forms and aggregate forms related to positive temperatures.

Morphology of neogenic carbonates from different zones is similar, but the intensity of mineral transformation is most intense in the transition zone where trans- formational processes become rock forming and results in formation of breccias. The transition zone is characterized by considerable temperature differences, sharp variations in solution saturation and formation of the so-called "gypsum powder", an intermediate product in the formation of large gypsum crystals originating both at temperatures above and below $0{ }^{\circ} \mathrm{C}$.

The features described here can be used as markers to identify paleoclimatic situations in karst cavities of carbonate-sulphate massifs.

\section{ACKNOWLEDGEMENTS}

The authors warmly thank E. Chirkova, T. Kalinina and B. Mavlyudov for their help in material processing and to Armstrong Osborne to improve English.

\section{REFERENCES}

Andreychouk, V.N., 1989: Problem questions of cave deposits classification.- Minerals and deposits of caves and their practical value, Perm, 4-6.

Andreychouk, V. \& E. Galuzkin, 2001: Cryogenic mineral formations of the Kungur Ice Cave.- Peshchery (Caves), 27-28, 108-116.

GOST, 1979: Russian Federation State Standard, 1253679 Soils.- Methods of laboratory determination of granulometric (grain) and micro-aggregate composition, pp. 24.
Lukin, V.S., 1968: Conditions and stages of the Kungur Cave formation. Karst of the Ural and Ural area.Proceedings of All-Ural conference, Perm, 39-42.

Tchaikovskiy, I.I. \& O.I. Kadebskaya, 2009: Cryogenic gypsum of the Kungur Ice Cave. Problems of mineralogy, petrography and metallogeny.- Proceedings of scientific readings in memory of P.N. Chirvinskogo, Perm, 12, 85-90.

Mavlyudov, B.R., 1994: Climate systems of caves: Questions of physical caving.- Interdepartmental collection, M.: MIPT, P., 6-24. 